Kinestetik : Jurnal Ilmiah Pendidikan Jasmani 5 (1) (2021)

Kinestetik : Jurnal Ilmiah Pendidikan Jasmani

https://ejournal.unib.ac.id/index.php/kinestetik/index

DOI : 10.33369/jk.v5i1.13630

\title{
DRIBBLE TRAINING MODEL DEVELOPMENT JUMP SHOOT BASKETBALL SPORTS BRANCH ON STUDENTS
}

\author{
Sabaruddin Yunis Bangun ${ }^{1 *}$, Tarsyad Nugraha ${ }^{2}$, Rian Handika ${ }^{3}$ \\ ${ }^{123}$ Faculty of Sport Science, State University of Medan, Medan, Indonesia
}

\section{Article Info}

Article History:

Received : November 2020

Revised : January 2021

Accepted : March 2021

Available online : March

2021

Keywords:

Basketball, dribble, Model

\begin{abstract}
This study aims to develop a dribble jump shoot training model in basketball. This type of research is research and development (Research and Development). In this development research, the product developed is a dribble jump shoot training model in basketball.The subjects in this research and development were 3 experts and 10 basketball athletes. The instruments used in this research and development were questionnaires and questionnaires used to collect data at the following stages: (1) needs analysis; (2) expert evaluation; (3) small group trials; and (4) field trials. The effectiveness test is the result of validation from 3 experts and the results of field tests. The results of the 3 experts stated that $86.25 \%$ was very suitable for use and the effectiveness test revealed a high gain value of 0.90 . Based on the results of research and development, it can be concluded that: (1) By developing an exercise model dribble jump shoot This, can help students in improving basketball jump shoot skills. (2) Provide a new reference for basketball jump shoot practice.
\end{abstract}




\section{INTRODUCTION}

Sport is a daily human activity that can form a healthy body and spirit. Currently, sports make a positive and tangible contribution to improving public health. Sports are not only for the benefit of education in schools, recreation and also physical fitness, but also as a place to build achievements. Of the many sports that have been developed, at this time one that must receive attention and guidance is basketball. According to Oliver (2007), basketball is one of the most popular games in the world. In our country, Indonesia also likes many basketball games from children to adults.

Yongvei (2017) states that basketball has the following characteristics: First, confrontation. The basketball competition venue is relatively small while the duration is short so players have to move, jump and shoot according to the situation. Second, teamwork. Basketball is played by a team so winning is based on teamwork. Third, deserve appreciation. In a game, players take turns attacking and defending where the situation is constantly changing. Meanwhile, passing, shooting, stealing and dipping worthy awards. Fourth, it's interesting. The rules are simple while the site restrictions are small. Due to the fact, how to play basketball can be adjusted so that it is full of fun. Fifth, it is constructive for fitness.

$$
\text { Aziz (2016) explains that }
$$

basketball athletes must master the basic techniques of playing basketball well individually. The basic techniques in basketball are passing, dribbling, shooting, pivoting and rebounding. Shooting ability is very important in basketball, but shooting can only be done when you get space, so dribbles are needed to find space and avoid guarding from opponents. In line with that Atavilla (2017) explains that in basketball, dribbling is a fundamental advantage: no player with the ball can move to the field if he doesn't dribble.

Apart from dribbling skills in basketball, shooting skills are also very important. In this case Khazaeli (2015) said that shooting is an important factor in determining results and to win matches. Khazaeli also said that there are various types of shooting techniques in basketball, namely jump shoots, free throws, hook shoots and lay up shoots. The jump shoot is the most powerful technique to get the points that get the most attention from coaches and players.

According to Iqbal (2015) Jump shoot is a very effective shot that is difficult for opponents to block. In line with that, Wijaya (2017) argues that the jump shoot is an effective shooting technique, because shooting in a jumping position with the initial squatting position will be very difficult to be blocked by the opponent. Based on these two opinions, it can be concluded that the jump shoot needs to be updated to become player mastery. The development of the dribble training model that will be made will be followed by a jump shoot exercise so that the students' achievement in playing basketball will be better.

Exercise is a very important factor in achieving maximum achievement, because achievement will be created from the results of training and hard work, but it is also necessary to develop it through regular and systematic training in order to develop optimally, Yahya (2012). According to Liu (2017)in the training process, actively guiding students to learn basketball should take precedence, so that the future development of students through basketball has a big help. At this stage, there are more methods of teaching basketball in the application of basketball, many basketball teachers have chosen the method of teaching basketball, in order to 
increase the level of students' ability in basketball.

Based on the results of the analysis of student needs at SMK Negeri 1, SMA Negeri 3, and SMA Private Kesuma Indah Padangsidimpuan obtained data that students who have the ability to bleed and jump shoot are not good by $70.75 \%$, students who feelneed to practice their dribble and jump shoot skills by $89.35 \%$, students who consider the current dribble and jump shoot exercises to be monotonous at $98.7 \%$, students who find it difficult to improve their dribble and jumpshoot abilities by 93.13\%, and students who agree that if the development of dribble training is carried out, immediately shoot a jump of $100 \%$. So it can be concluded that there needs to be a development in the dribble jump shoot exercise carried out by students so that their dribble jump shoot ability is better.

\section{METHODS}

This research was conducted at SMK Negeri 1, SMA Negeri 3, and SMA Private Kesuma Indah Padang Sidimpuan.

\section{The scope of research}

Before starting the research, the researcher determines the components of the research scope.

a. Research Object: To create a new basketball dribble jump shoot training model

b. Research subjects: 3 experts and 10 basketball athletes

\section{Research methods}

Research and development $(\mathrm{R} \& \mathrm{D})$ is a research method used to develop or validate products used in education and learning. This research and development uses qualitative and quantitative approaches and uses the Research \& Development (R\&D) development model from Sugiyono
(2016) which consists of ten steps. The ultimate goal of this research and development is the creation of a basketball dribble jump shoot training model

\section{Materials and Apparatus}

Materials and equipment in this study are:

1. A student who can play basketball.

2. Basketball Court

3. Basketball

4. Research Instruments

5. Office stationery

6. Research activity recording device and camera

7. Kun practiced

8. Whistle

\section{Procedures}

The procedure used in this development research adopts the model proposed by Brog \& Gall in Sugiono(2015). The steps taken in this development research will also be adjusted to the limited time of the study, the following steps are described in this study:

1. Analyzing Potentials and Problems

Potential and problem analysis is intended to find predecessor sources in the form of the problem faced and to find out how important a product is needed in overcoming problems encountered in learning and training activities.

2. Do some research to gather initial information

This stage is intended to obtain data that supports the truth of the problems found. This can be done through observation, interviews, and conducting an initial needs analysis. This stage was carried out by researchers on basketball extracurricular activities at SMK Negeri 1, SMA Negeri 3, and SMA 
Private Kesuma Indah Padangsidimpuan.

3. Make Product Design

This stage includes making product designs, compiling sources of materials and materials and arranging products. Researchers consult with lecturers or basketball experts, look for reference books, take pictures and edit.

4. Design Validation

From the results of product development, the next step is to test the validity of the design by material experts in the field of basketball and media experts.

\section{Design Revision}

Based on design validation, the incoming data is then used as a reference in revising the product design. The results of the first product revisions are then used in product trials (small group trials). This trial is intended to obtain various inputs and corrections regarding the products that have been produced.

\section{Product Manufacturing}

After collecting preliminary information from some relevant research, observing the training process in the field, and watching videos about basketball training, making designs and revising the design, a product is made, namely an instructional video of a direct dribble jumpshoot training model. Product manufacturing is carried out with the help of several people who hold their respective roles, including: athletes, cameramen, security team, editors. Besides that, it also uses several tools such as studio video cameras, photo cameras, camera stabilizers, tripods, laptops, primary Adobe applications, basketball, courts, rings, kuns, and whistles.

7. Limited Trial

This trial is intended to obtain assessments, inputs and corrections on previously revised products. The trial of this product was carried out with the research subjects, namely athletes at SMK Negeri 1 Padangsidimpuan who participated in basketball extracurricular activities with a total of 25 people.

\section{Product Revision 1}

Based on product trials, the incoming data is then used as a reference in revising the product. The results of the second product revision were then used in testing usage.

9. Main field trials

Field trials were carried out by asking students to use the product and evaluate it, through a questionnaire that had been provided. This is intended to obtain assessments, inputs and corrections on products that have been revised and tested previously. The use trial was carried out by involving athletes who took part in basketball extracurricular activities at SMA Negeri 3 and SMA Private Kesuma Indah Padangsidimpuan with a total of 78 people as research subjects.

\section{Design or Data Analysis}

For product design, the development of a basketball dribble jump shoot training form is quoted from Borg and Gall in Sugiyono having the following steps: 


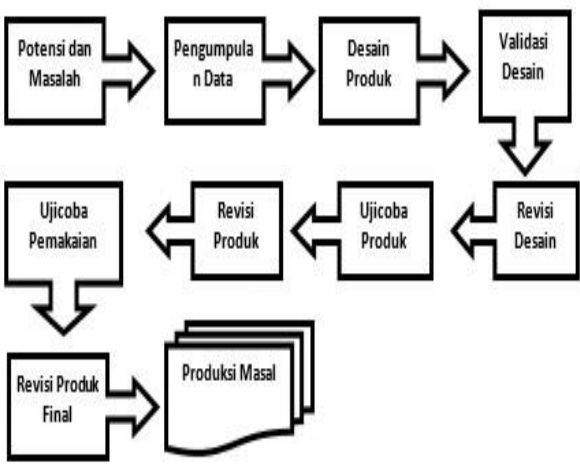

Figure 1. Research Series of Research and Development Methods, Sugiyono (2016)

\section{DISCUSION}

Development research is research that is based on making an effective product, starting with a needs analysis, product development, and product testing, Riza (2015)

Exercise is a systematic process of practicing or working repeatedly to get the expected results, Darmawan (2014). In line with that Supriadi (2014) states that training to master a skill requires a long and planned program. Training activities must use the principle of learning, namely in learning to have the aim of mastering a knowledge or skill carried out in several stages. Based on this statement, it can be concluded that sports activities are never separated from the training or learning carried out between coaches and athletes and must be structured so that during the training process they can create maximum results as expected.

The experts who became the validators in this study consisted of 4 people. Researchers chose them as experts because their competence in the field of basketball is very adequate. The assessment from material experts is carried out in two stages. The assessment process is carried out by filling out a questionnaire that was included during the validation process. Phase I validation from the material aspect is declared fit for production with revisions as recommended, and stage II validation is declared very feasible for production without revision and the product may be tested.

The results of the evaluation from material experts on the products developed can be seen in Figure 2 Diagram of the Average Percentage of Values of the Expert's Dribble Jump Shoot Training Model.

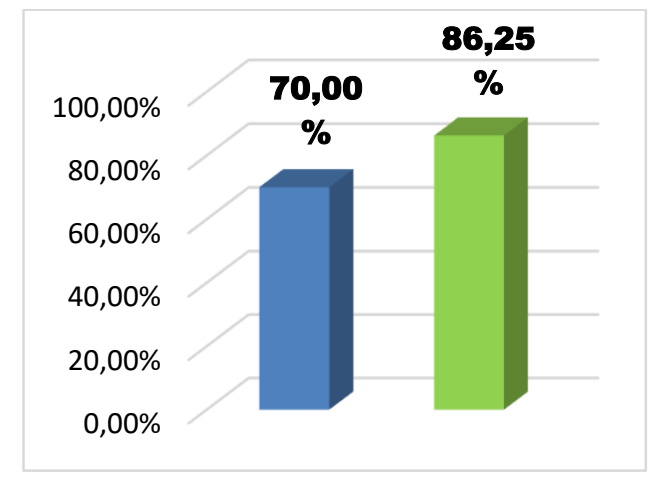

Figure 2. Diagram of the Average Percentage of Value for the Exercise Model

Dribble Expert jump shoot

The mean percentage value for the dribble jump shoot training model from the material aspect in the first stage is $70.00 \%$, then the average value obtained is included in the "Eligible" criteria. In stage II, the percentage mean value of $86.25 \%$ is included in the criteria of "very feasible".

In Figure 2, the average percentage value of the dribble jump shoot training model from the expert shows the difference in the mean percentage value of the dribble jump shoot training model from the material aspect where the percentage difference in stage I and stage II can be said to be quite large, amounting to $16.25 \%$. The percentage value in stage $\mathrm{I}$ is lower than in stage II, which means that there is a good change in the training model after being revised.

The quality of the dribble jump shoot training model obtained from small group trials as a whole is in the very feasible category indicated by a percentage 
of $87.09 \%$ and from the field trials as a whole it is included in the very feasible category indicated by a percentage of $91.19 \%$.

After being declared fit for production, the dribble jump shoot training model was used in further research. This further research was conducted to determine how much influence the dribble jump shoot training model has in increasing the basketball athlete's jump shoot ability.

This research was conducted on 10 basketball athletes. Before being treated, a pretest was carried out to see the athlete's initial ability to perform a jump shoot movement. After the pre-test, the athletes were given treatment, namely doing exercises using the dribble jump shoot training model for 2 weeks. After going through the training process, the athletes take a test post to see their jump shoot ability after being treated. The average pretest, post-test scores, and the increase in the athlete's score (gain) can be seen in Table 1 Summary of Average Values Obtained by Athletes

Table 1. Summary of Average Score

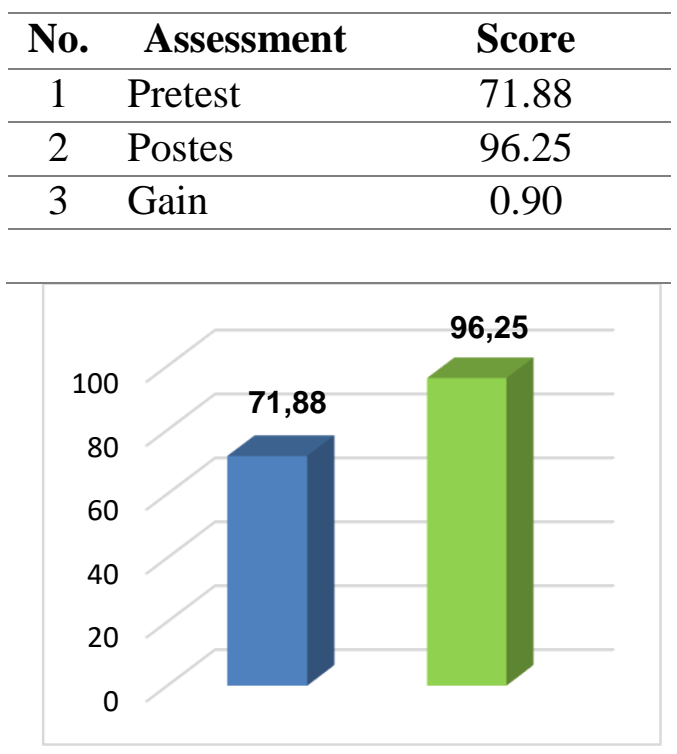

Figure 3. Comparison diagram of pre-test and post-test scores for athletes
From Table 1, Summary of the Average Score Obtained by Athletes, it can be seen that the average pretest score for athletes is 71.88 . The average post-test score of the athletes was 96.25. Based on the acquisition of pretest and posttest scores, the athletes' gain can be calculated. The average gain obtained is 0.90 , so this value is included in the "high" category, meaning that the increase in the value of athletes who exercise with the dribble jump shoot training model is high.

Figure 3 Comparison diagram of the Pre-test and Post-test scores of Athletes shows the comparison of the average pretest and post-test scores of athletes. From this figure, it can be seen that the average pre-test score is lower than the average post-test score of the athletes. Based on the results of the assessment of all experts as well as trainers, the whole at the initial stage, namely the product feasibility test, is included in the "very feasible" criteria for testing.

Products that have been declared very feasible to be produced are then tested on 10 athletes to see the effect of training media on athletes' jump shoot abilities. From the trials conducted, it was found that the increase in the score of athletes who exercised the jump-shoot ability of the athletes was 0.90, including the "high" category, meaning that the athletes' jumpshooting ability had a high effect on the athlete's jump-shoot ability. According to Safitri (2013), a player who can shoot a jump shoot well is a dangerous threat to his opponents in scoring points. If the player has control of the ball, he can score at any time because the player can take a jump shot from any situation, for example when doing a dribble,

A limitation of this study is the difficulty of gathering athletes. The timing of the research is difficult to determine due to differences in schedules with athletes. The training model 
presented is not suitable for novice athletes. Limitations of collecting athlete's schedule. Limitations of a basketball court that are not in accordance with standards.

\section{CONCLUSION}

Based on expert validation and trials, a basketball dribble jump shoot training model product has been produced which turns out to be entirely feasible to use. This is based on the discussion of the results of the product trial analysis.

Based on the results of testing the effectiveness of the model, it is empirically proven that the product in the form of a basketball dribble jump shoot training model has a very good effectiveness. This is based on the results of the basketball jump shoot skill test which shows that the average post-test result is greater than the average pre-test result. So that it can be stated that, this training model is effective for improving basketball jump shoot skills.

\section{REFERENCES}

Aziz, A. (2016). Faktor Fisik dan Teknik Pada Kemampuan Dribble Atlet Ekstrakurikuler Bola Basket Putra Tingkat SMA. Pend. Kepelatihan Olahraga-S1, 1 (6).

Altavilla, G., Di Tore, A. P., D'Isanto, T., \& Raiola, G. (2017). Some Teaching Method Elements of the Basketball Dribble. Journal of Sports Science, 5, 207-210.

Darmawan, A. B., Januarto, O. B., \& Wahyudi, U. (2016). Pengembangan Model Latihan Kombinasi Dribbling, Passing dan Shooting Peserta Ekstrakurikuler Bolabasket di SMP Negeri 2 Kota Malang. Jurnal Pendidikan Jasmani, 26 (2).

Ji, R. (2020). Research on Basketball Shooting Action Based on Image Feature Extraction and Machine Learning. IEEE Access, 8, 138743138751.
Iqbal, K., Abdurrahman, A., \& Ifwandi, I. (2015). Kontribusi Daya Ledak Otot Tungkai dan Keseimbangan terhadap Ketrampilan Jump Shoot dalam Permainan Bola Basket pada Atlet Unit Kegiatan Mahasiswa Universitas Syiah Kuala. Jurnal Ilmiah Mahasiswa Pendidikan Jasmani, Kesehatan dan Rekreasi, 1(2).

Khazaeli, M. A., Sadeghi, H., Rahimi, A., \& Mirmoezzi, M. (2015). Comparison Of Selected Kinematic Parameters Of The Ball Movement At Free Throw And Jump Shot Of Basketball Adult Players. Indian Journal of Fundamental and Applied Life Sciences, 5(S3), 25492553.

Liu, F. (2017). Study on Strategies of Basketball Game in Basketball Teaching. International Conference on Frontiers in Educational Technologies and Management Sciences (FETMS 2017).

Oliver, John. (2007). Dasar-dasar Bola Basket. Pakar Raya: Bandung.

Riza, Ade Ros. (2015). Pengembangan Model Pembelajaran Voli Forehand Tenis Lapangan. Jurnal Pedagogik Olahraga, $1(1)$.

Safitri, Nuvanda Eka. (2013). Pengaruh Jump Shoot didahului Dribble dan Passing terhadap Hasil Jump Shoot pada Tim O2SN Bolabasket Putra SMK Kota Pekalongan Tahun 2013. SKRIPSI. Fakultas Ilmu Keolahragaan Universitas Negeri Semarang.

Sugiono. (2016). Metode Penelitian Pendidikan. Bandung: Alfabeta.

Supriadi, Amir. (2017). Hubungan Koordinasi Mata-Kaki Terhadap Keterampilan Menggiirng Bola Pada Permainan Sepakbola. Jurnal Ilmu Keolahragaan, 14(1).

Wijaya, R. A. (2017). Pengaruh Latihan Jump Stop Shoot dan Triple Threat Position Terhadap Hasil Jump Shoot Putra Ekstrakurikuler Bola Basket SMA Negeri 2 Pringsewu Tahun 2016/2017. (Bachelor's thesis, Universitas Lampung: Fakultas Keguruan dan Ilmu Pendidikan).

Yahya, Y. (2012). Kontribusi Kecepatan dan Kelincahan Terhadap Keterampilan 
Dribble Bola Basket Mahasiswa Jurusan Pendidikan Jasmani Kesehatan dan Olahraga Universitas Riau. Perspektif, 3(6), 160-168.

Yongvei, Bin Li, Bin Niu. (2017). A Model Research of Basketball Teaching and Training Aided System in Colleges and Universities Based on Video Image Processing Technology. Revista de la Facultad de Ingeniería, 32 (14). 